\title{
Removal of Odontogenic Keratocyst in Maxilla Through the Le Fort I Osteotomy
}

\author{
Eliminación de Queratoquiste Odontogénico en el Maxilar \\ Mediante la Osteotomía Le Fort I
}

Brancher, G. Q. B.'; Cavalieri-Pereira, L.'; Pedroso-Oliveira, G. ${ }^{1}$; Macedo, C. J. O. ${ }^{1}$; Altafin, L. ${ }^{1}$ \& Cavalieri-Pereira, S. ${ }^{2}$

BRANCHER, G. Q. B.; CAVALIERI-PEREIRA, L.; PEDROSO-OLIVEIRA, G.; MACEDO, C. J. O.; ALTAFIN, L. \& CAVALIERIPEREIRA, S. Removal of odontogenic keratocyst in maxilla through the Le Fort I osteotomy. Int. J. Odontostomat., 14(2):249256, 2020.

ABSTRACT: The odontogenic keratocyst is a lesion with specific clinical and histopathological aspects. The World Health Organization (WHO) in 2017 reclassified it from a tumor to a cyst. It is characterized as a cyst of epithelial development of the jaws, arising from the remains of the dental blade. It represents $3 \%$ to $11 \%$ of all odontogenic cysts and 7 to $11 \%$ of cysts of the gnatic bones. It stands out for its aggressive nature and high relapsing potential. Most of the cases are diagnosed in individuals between 10 and 40 years old, with a mild preference for the masculine gender, occurring more in the mandible. Radiographically, it is radiolucent and well delimited, predominantly unilocular, and may cause displacement of adjacent teeth. The present study aims to report a clinical case of a female 25 years old patient, presenting an intra-osseous lesion in the maxilla (posterior, left side), asymptomatic, with a slight increase in intraoral buccal volume, containing the tooth 28 , with a diagnostic hypothesis of Odontogenic Keratocyst. The patient was submitted to the surgical decompression treatment, with cystic fluid puncture, biopsy of the lesion and posterior anatomopathological examination. The enucleation of the tumor was performed using LeFort I osteotomy of maxilla and reconstruction with titanium mesh. There is radiographic evidence of bone repair and lesion reduction. The patient is in periodic follow-up of 4 years and does not present clinical and radiographic signs of relapse. Due to the aggressiveness of the odontogenic keratocyst, the relapse rate is high. The knowledge of the techniques recommended for the treatment of Odontogenic Keratocysts and the clinical and radiographic follow-up of the patient demonstrate a gradual decrease of the lumen of the lesion and suggest local bone neoformation, favoring the prognosis of the case.

KEY WORDS: odontogenic cysts, maxilla, osteotomy, therapeutics.

\section{INTRODUCTION}

Odontogenic keratocyst is a lesion with clinical behavior and specific histopathological features (Waldron, 2009), being unique due to its aggressive nature and high relapsing potential. It usually has a slow behavior and many are diagnosed on routine dental radiographs (Hunter et al., 1996), as they are largely asymptomatic (Shear, 2002), without causing obvious bone expansion (Waldron), leading to clinical expansion only belatedly.

It represents between $3 \%$ and $11 \%$ of odontogenic cysts (Zachariades et al., 1985). About $60 \%$ of the cases are diagnosed between the $2 \mathrm{nd}$ and 3rd decades of life (Waldron), but may also occur in infancy (Khalique \& Rippin, 1992), with a slight male predilection (1.44: 1). The mandible is affected in 60 to
$80 \%$ of the cases (2:1 relation to the maxilla), with a high tendency of involvement of the mandibular ramus (Waldron) and maxilla is affected in only $13 \%$.

It has a thin, friable cyst capsule with liquid content or cheesy material. Radiographically, it presents as a circular or ovoid, radiolucent, halosclerotic, predominantly unilocular lesion (Zhao et al., 2002), which may cause displacement of adjacent teeth and involve a retained tooth.

Although benign, it is locally aggressive and shows a tendency to recur after treatment, ranging from 3 to 60 \% (Shear; Madras \& Lapointe, 2008) depending on tumor site and type of treatment adopted (MacDonaldJankowski, 2011; Kaczmarzyk et al., 2012). 


\section{CLINICAL CASE REPORT}

The clinical case report is from the 25-year-old female white patient, who sought the Oral and Maxillofacial Surgery and Traumatology Service at Hospital dos Fornecedores de Cana de Piracicaba presenting a volumetric increase in posterior left side of the maxilla. At the clinical examination, swelling was observed in the left buccal mucosa of maxilla, hardened to palpation (Fig. 1B). The patient was submitted to decompression and biopsy in another service, obtaining as a result of the anatomopathological examination the diagnosis of odontogenic keratocyst.

A panoramic radiograph shows a well-defined, rounded, unilocular radiolucent area with regular margins, radiolucent center and halo sclerotic, in the posterior maxilla, displacing the teeth 25 and 26 , involving a large part of the bone support of the roots of the 27 tooth, containing the 28 tooth within the maxillary sinus (Fig. 1A).

On the facial computed tomography scan, it is observed a veiled maxillary left sinus in axial sections, with a bulging of the buccal wall of the maxilla and the right maxillary sinus without alterations. The extension of the tumor to the posterior region is verified, compressing the infra-temporal fossa and the pterygoid

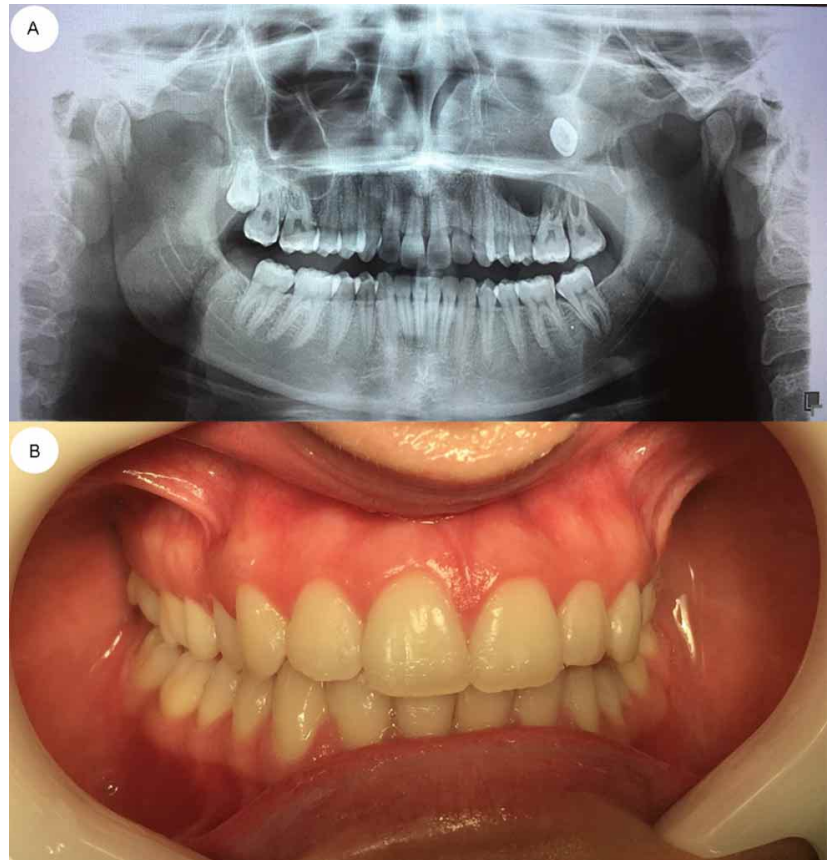

Fig. 1. A. Panoramic radiography, after decompression; B. Intraoral view of presented occlusion.

space by the expansion of the cortical, in addition to compression of the nasal cavity. It is observed a greater length of the lesion in the anteroposterior direction (51.72 $\mathrm{mm}$ in its greatest dimension), associated to the tooth 28 in an ectopic position (Fig. 2A).

up, corroborating with authors such as and Tucker et al. (1972), Brøndum \& Jensen (1991), Marker et al. (1996), Johnson et al. (2013) and Lee et al. (2017).

Only a few cases of maxillary sinus keratocysts have been reported in the literature (Cakur et al., 2008; Scolozzi et al., 2009;
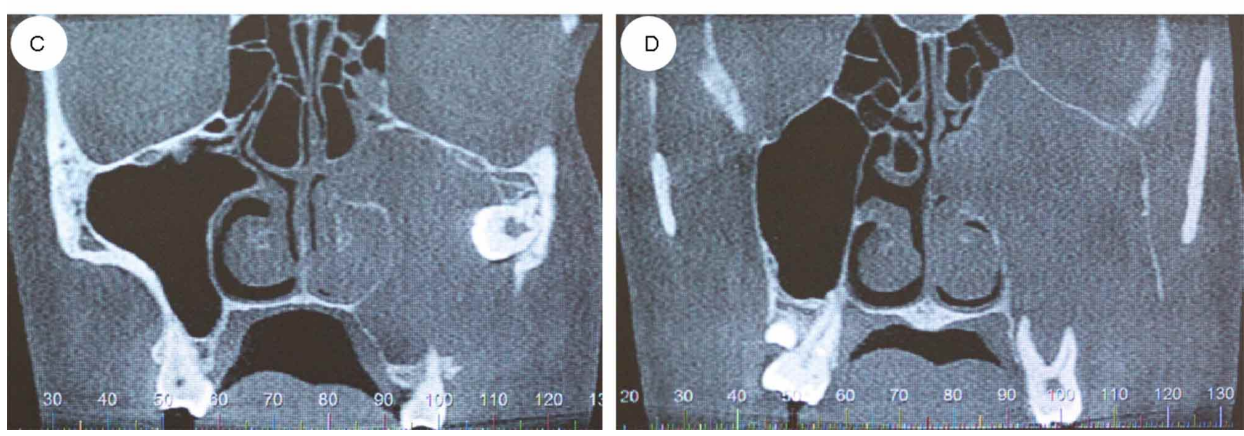

Fig. 2. CT scan performed after decompression of the cyst in the left maxilla; A. Axial section; B. Sagittal section; C. Coronal section; D. Coronal section. 
In a sagittal section, tumor expansion towards the orbital cavity is seen, as well as deviation of 25 and 26 teeth roots, and normal contralateral side (Fig. 2B). In coronal sections, the extension of the tumor to the ethmoidal sinuses region and nasal cavity is visualized (Fig. 2C, D).

On computed tomography scan performed after 1 year after decompression, it is possible to evaluate the effects of this procedure: reduction on the increased size of the lesion is noted, as well as a mucosal thickening and calcification of the margins of the left maxillary sinus, containing impacted 28 tooth; regression of the expansion towards the infra-temporal fossa and nasal cavity and normal aspect of the right maxillary sinus. In sagittal sections, the regression of the expansion towards the orbital cavity and the decrease in the size of the tumor are noted. In coronal sections, intact ethmoidal sinuses and intact nasal cavity are observed, demonstrating tumor regression (Fig. 3).
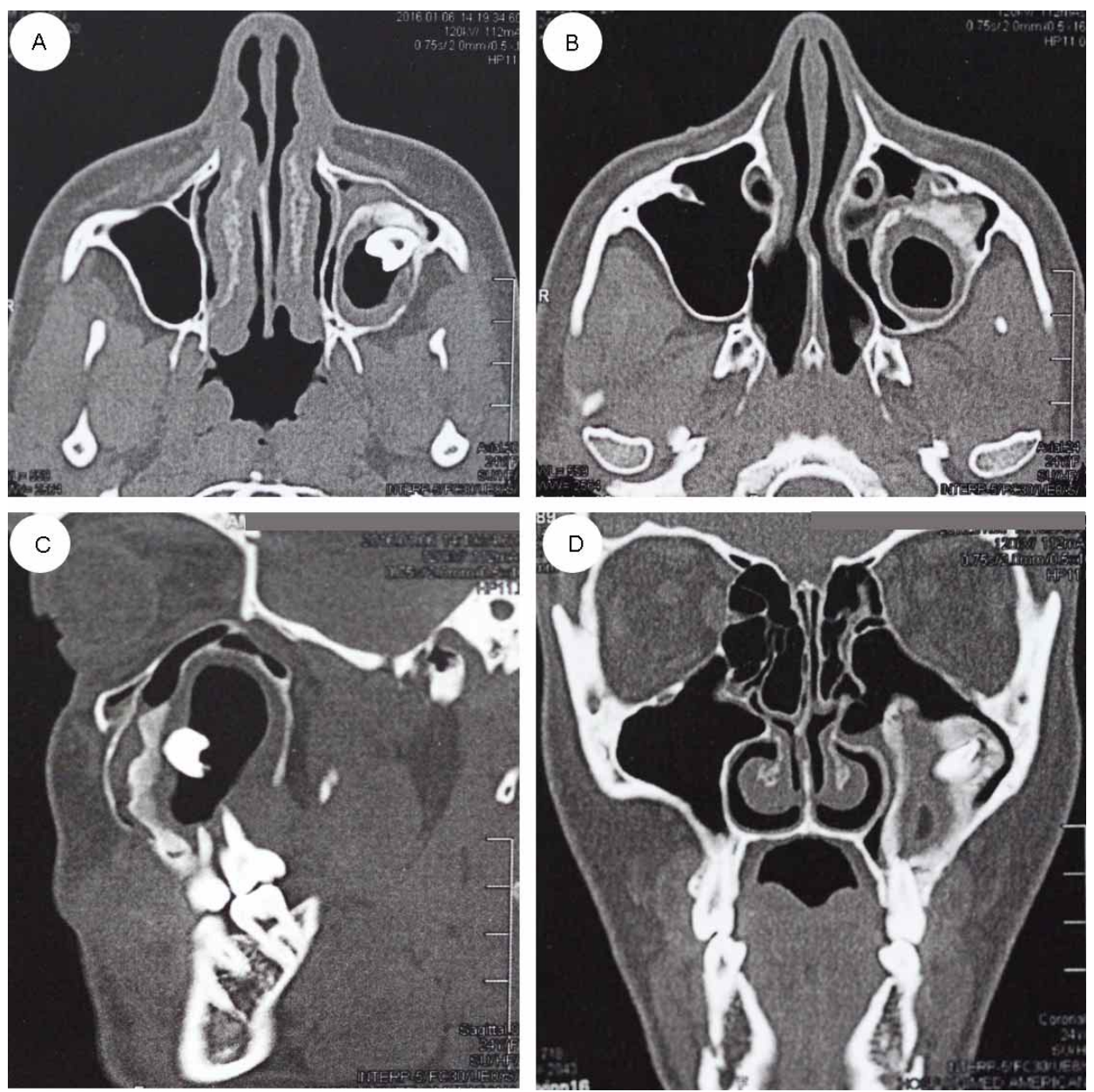

Fig. 3. CT scan performed 1 year after left side maxillary cyst decompression procedure.
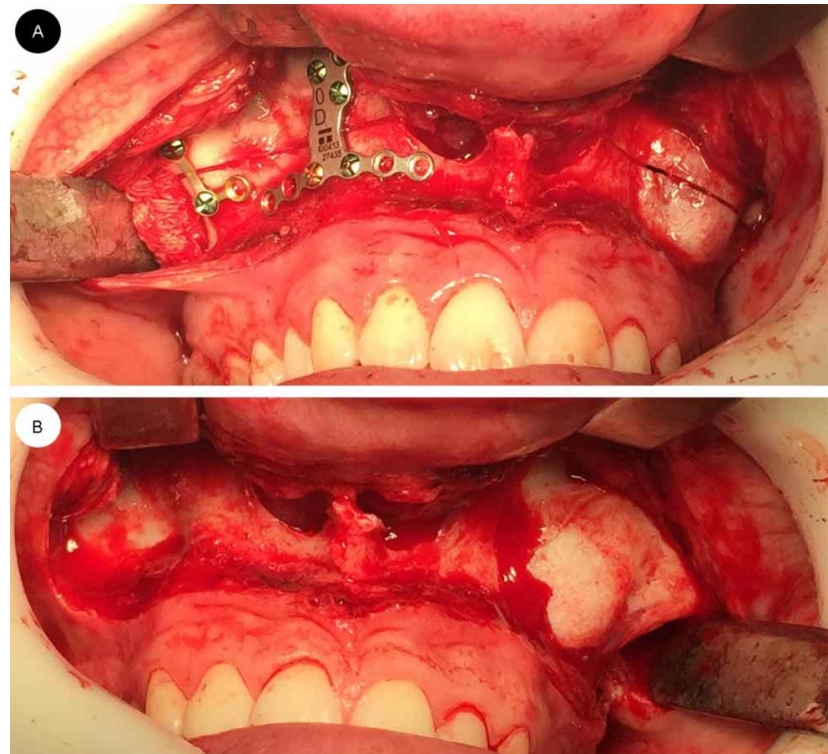

Fig. 4. Trans-operative pictures of the odontogenic keratocyst enucleation surgery in the posterior region of maxilla. A. Anterior wall appearance; B. Installation of plates after Le Fort I Osteotomy, as a reference to posterior fixation of the maxilla.

The enucleation of the cyst was determined as a treatment plan, using the Le Fort I Osteotomy technique as a surgical approach. Therefore, after one year of the Decompression procedure, the patient was submitted to the Odontogenic keratocyst enucleation, performed in a hospital setting, under general anesthesia and nasotracheal intubation.

The expansion of the left wall of the left maxilla is observed, after access to bilateral vestibular mucosa for Le Fort I Osteotomy, performed using electric scalpel, and mucoperiosteal detachment (Fig. 4A). Then, the bilateral Le Fort I Osteotomy was performed using a reciprocating saw.

Two well-adapted 1.5 $\mathrm{mm}$ miniplates were installed on the right side of 

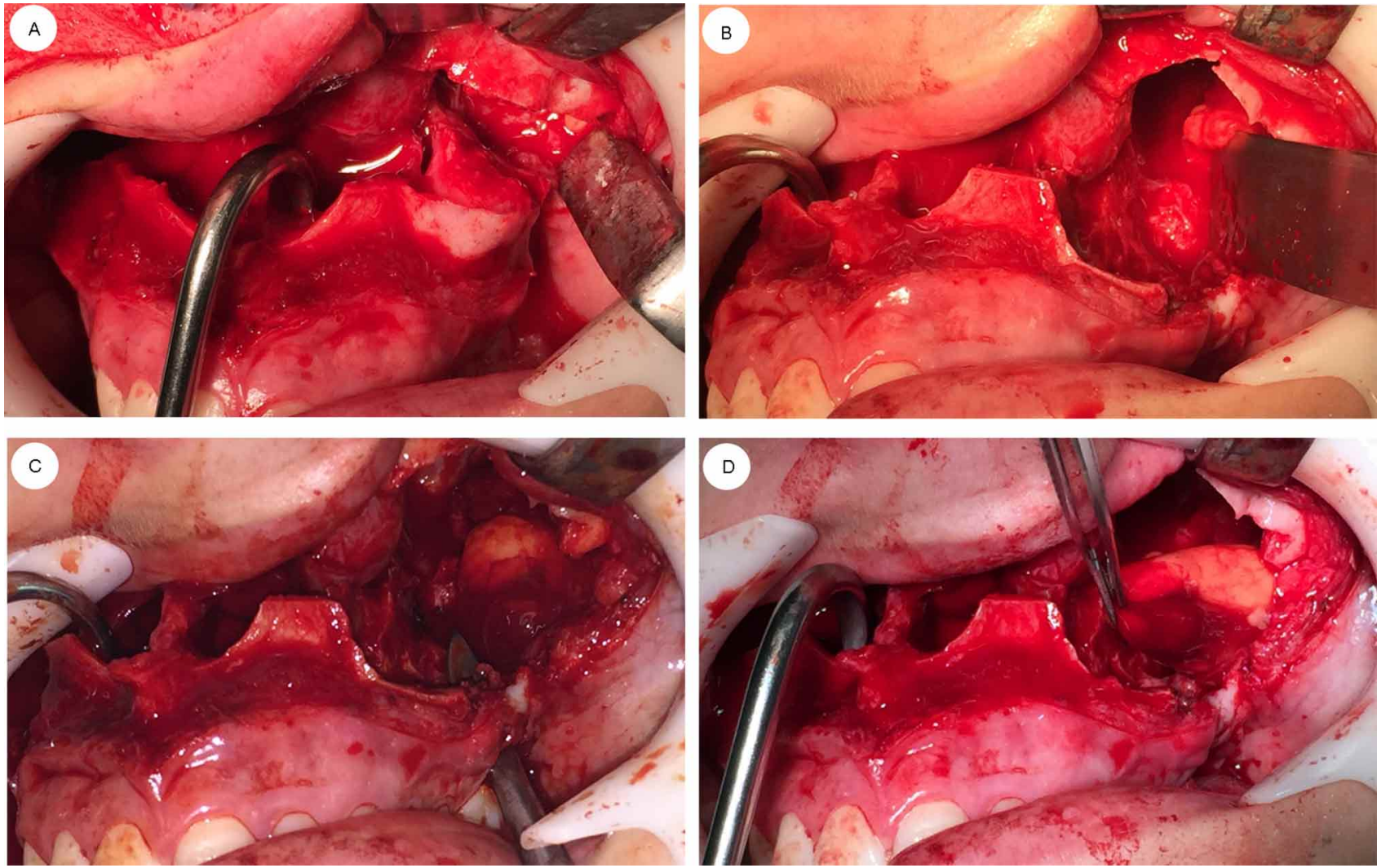

Fig. 5. Trans-operative pictures of the odontogenic keratocyst enucleation surgery in the posterior region of maxilla. A Maxillary downfracture and keratocyst exposure; B - Removal of the cystic lesion, associated with peripheral ostectomy; COroantral communication in the region of extraction of tooth 27; D - Tracing of buccal fat pad graft.

the maxilla, which were then removed, in order to serve as a reference in posterior maxillary repositioning (Fig. 4B).

After maxillary downfracture, the cystic mass was exposed, adhered to the lateral wall of the maxillary sinus and 27 root apices (Fig. 5A). Therefore, cystic enucleation was performed, removing the mass, which had calcified margins and hardened consistency, as well as removal of the unerupted 28 tooth. Subsequent peripheral ostectomy was performed with a rotating instrument, to provide a safety margin after excision, regularization of walls and removal of residual cystic epithelium (Fig. 5B). Removal of tooth 27 was also performed, creating an oroantral communication (Fig. 5C). It was thus necessary to reposition the left buccal fat pad through its divulsion and traction (Fig. 5D). Finally, maxilla was repositioned and the pedicled buccal fat pad graft was sutured, in order to close the communication.

After maxillary repositioning, maxilla was fixed using $1.5 \mathrm{~mm}$ miniplates and screws: 2 pre-folded miniplates in canine pillars and 1 "L" miniplate in right zygomatic pillar (Fig. 6A), as well as the fixation of a titanium mesh with miniscrews of the $1.5 \mathrm{~mm}$ system on the anterior wall of the sinus, due to the great bone defect, in order to reconstruct it and support the soft tissue (Fig. 6B).

At the end of the procedure, occlusion was reestablished due to plate-laying technique prior to downfracture (Fig. 6C). The aspects of cystic lesion were removed (cystic capsule and bone fragments), as well as teeth 27 and 28 (Fig. 6D).

On computed tomography scan of 1-year postoperative follow-up, the left maxillary sinus seems permeable, free of lesion, and there is presence of osteosynthesis material in the anterior wall of the maxillary sinus, without signs of recurrence lesion. In sagittal and coronal sections, the left maxillary sinus is observed in normal dimensions (Fig. 7). Patient is in periodic postoperative clinical and tomographic followup. Until the present postoperative moment, there was no sign of recurrence of the lesion. 

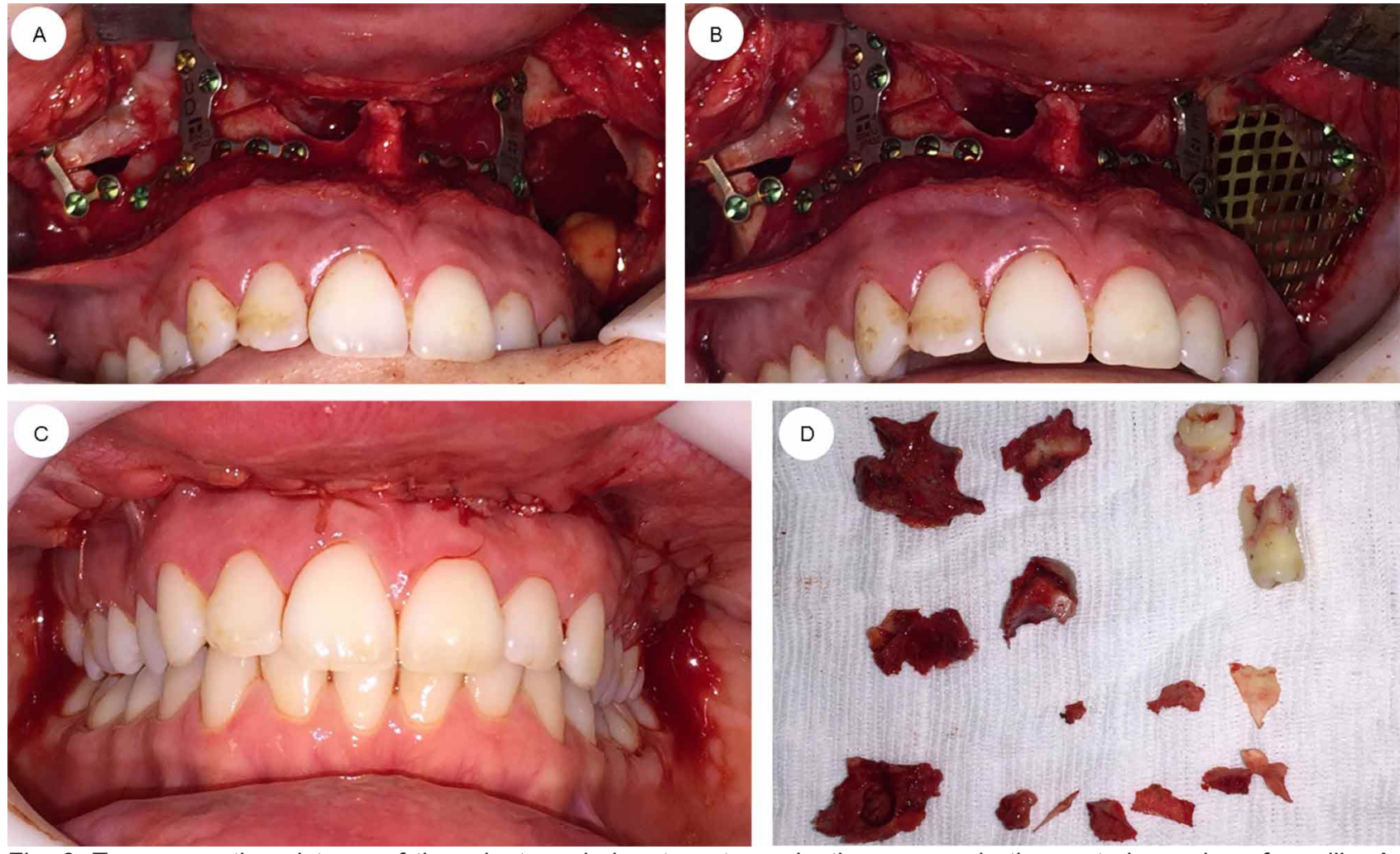

Fig. 6. Trans-operative pictures of the odontogenic keratocyst enucleation surgery in the posterior region of maxilla. A. Maxillary fixation with 1,5 $\mathrm{mm}$ system plates; B. Fixation of a titanium mesh on the left side of the maxilla; C. Restored occlusion; D. Cystic fragments, bone and teeth 27 and 28 removed.
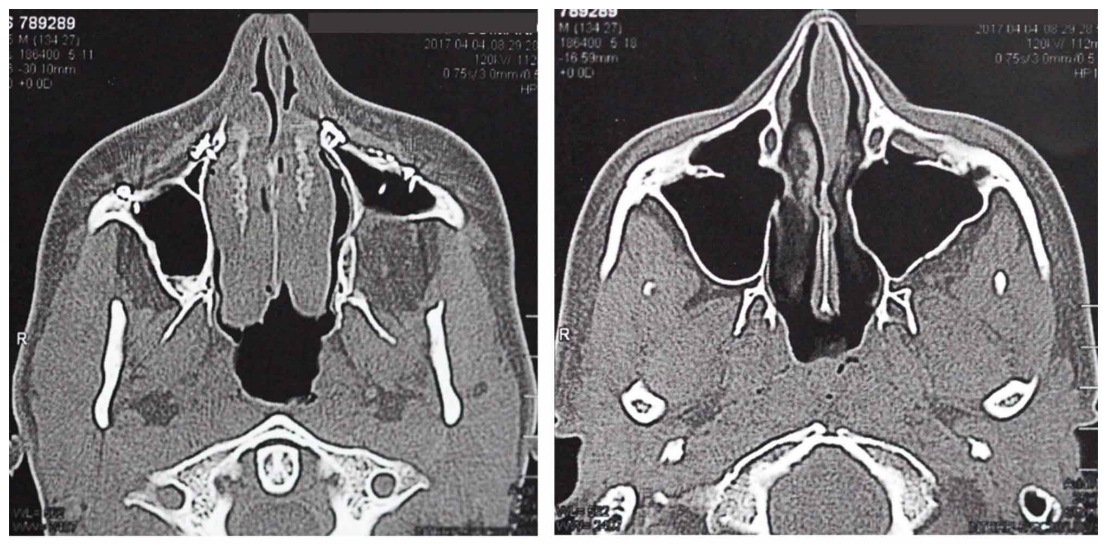

\section{DISCUSSION}
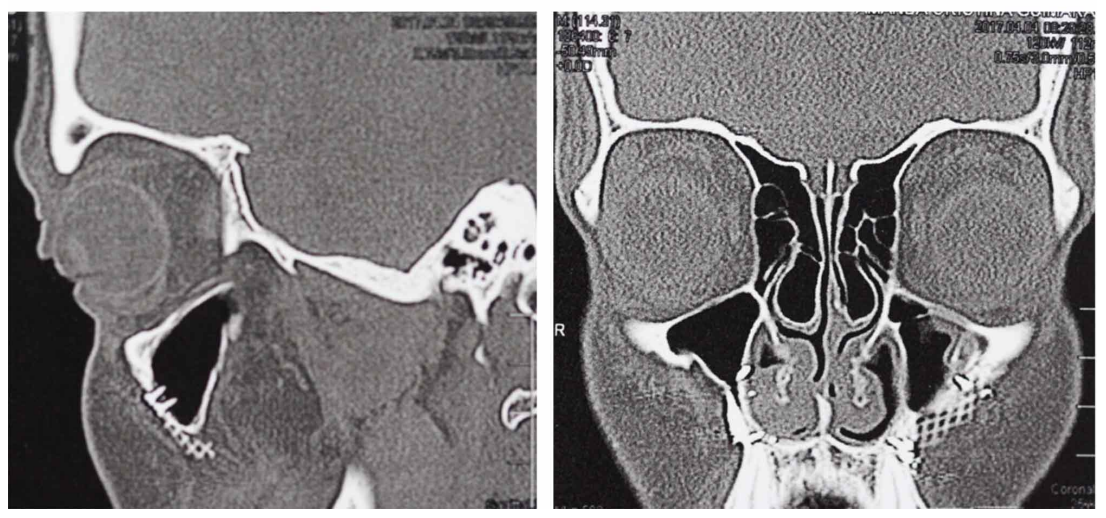

Odontogenic keratocysts can initially be treated with incisional biopsy and decompression by installing a polyethylene drain to allow subsequent reduction of the cystic cavity size, resulting in thickening of the capsule, which allows a later easy removal withapparently lower relapse rate (Waldron).

The principle of treatment of odontogenic keratocysts in this OMF Surgery Service is based on previous decompression, followed by enucleation with peripheral ostectomy and clinical and radiographic follow-

Fig. 7. CT scan performed one year after odontogenic keratocyst enucleation surgery - axial, sagittal and coronal sections. 
Byun et al., 2013; Kunihiro et al., 2014; Zhou et al., 2014; Lacarbonara et al., 2014). These authors report the slow growth of these cysts located in the maxillary sinus, which leads to late clinical signs and symptoms, as they grow without producing evident bone expansion.

Odontogenic keratocysts associated with maxillary sinus ectopic teeth were described in literature by Wetmore et al. (1983), Shenoy et al. (1988) and Woodall \& Wood (1993). Hunter et al. first described a case of a keratocyst in bilateral maxillary sinus, associated with ectopic teeth.

Surgical access to a lesion should be determined by its location, its size, its stage and the effectiveness of the embolization (Paris et al., 2001). In the literature, surgical techniques are proposed for access to the maxillary sinus, including Caldwell-Luc osteotomy, Weber-Fergusson access and trans-maxillary access through the Le Fort I osteotomy.

To allow total removal of an odontogenic keratocyst in the maxillary sinus, an extensive approach is often required, such as that allowed by Le Fort I Osteotomy. This technique is one of the access modalities for the removal of maxillary tumors and extensive tumors in skull base and paranasal sinuses. It offers a panoramic view of the nasal cavity and the maxillary sinus (Wood \& Stell, 1989; Buchanan \& Hyman, 2013), allows direct and general vision of the surgical field and better exposure of the lesion compared to the Caldwell-Luc approach, besides offering a better aesthetic result when compared to Weber-Fergusson access (Colreavy et al., 2001).

The Le Fort I Osteotomy proposes a circumferential access to the entire lesion, allowing the removal of the whole lesion, as well as good exposure with minimal removal of bone tissue. It does not present direct risks to the main nerves and blood vessels (Karci et al., 2001). Its rare complications include postoperative haemorrhage, subcutaneous emphysema and maxillary necrosis (Lewark et al., 2000). There are no reports of changes in dental sensitivity by patients, thus becoming a well-indicated technique (Lowlicht et al., 2002).

The Weber-Fergusson approach is considered more aggressive than the Le Fort I osteotomy technique (Byun et al.). It is the necessary access for resection of large lesions. The surgery time is longer and causes visible scars on the face, which would cause an undesirable aesthetic sequel in a young patient.
For this clinical case, the enucleation of the cyst through the Le Fort I Osteotomy, as a surgical approach to removal of large maxillary lesions, was determined as a treatment plan, corroborating with the treatments proposed by the following authors: Catunda et al. (2011), Leite Segundo et al. (2007), Scolozzi et al., Korpi et al. (2009), Moura et al. (2016) and Alstad \& Abtahi (2017).

After enucleation, at the same surgical time, the cystic tissue was cured and peripheral ostectomy was performed with a rotating instrument, aiming to provide a safety margin after excision, regularization of walls and elimination of residual cystic epithelium, as described by authors such as Bataineh \& AI Qudah (1998), Meiselman (1994), Schultz et al. (2005) and Kolokhytas et al. (2007).

Regezi et al. (2008) cited cyst enucleation associated with peripheral ostectomy as the preferred method of treatment. Habibi et al. (2007) demonstrated that marsupialization followed by surgical enucleation was efficient, following no recurrence.

As for the high rates of relapse, the factors responsible for this important characteristic of those cysts are cited in the literature, such as limited surgical access and technical difficulty for complete removal, especially in the posterior maxilla region (Johnson et al.), thin and friable cystic capsule, cyst size, multilocular shape and complications such as infection or perforation with keratin overflow in soft tissue.

Although about $70 \%$ of keratocysts recur within 5 years' post-surgery, a significant number of relapses may not present until 10 or more years after the original surgical procedure (Waldron). Annual clinical and radiographic follow-up of these patients is therefore recommended for indefinite period (Brøndum \& Jensen).

According to Alstad \& Abtahi, a recurrence rate of $33 \%$ was found for keratocysts in the maxillary sinus at an average follow-up of 7 years, where all patients with recurrence had multilocular lesions. However, the authors describe that the cause of the high recurrence rate is not recognized, and may be related to tumor multilocular shape, difficulty in removing the lesion in its entirety or the combination of these two factors.

\section{CONCLUSION}

The knowledge of the indications of different techniques and approaches for odontogenic keratocysts 
located in maxilla, of its characteristics, aggressiveness and the high rate of relapse, allow early diagnosis and treatment, as well as adequate surgical treatment, with favorable prognosis.

It is concluded that the Le Fort I osteotomy constitutes a reliable approach for access and removal of lesions in the paranasal sinuses, including the maxillary sinus. It represents a safe and versatile osteotomy, which allows excellent surgical exposure for resection of tumors on skull base and on paranasal sinuses, as it provides direct access, rapid tissue healing and aesthetic results.

BRANCHER, G. Q. B.; CAVALIERI-PEREIRA, L.; PEDROSOOLIVEIRA, G.; MACEDO, C. J. O.; ALTAFIN, L. \& CAVALIERIPEREIRA, S. Eliminación de queratoquiste odontogénico en el maxilar mediante la osteotomía Le Fort I. Int. J. Odontostomat., 14(2):249-256, 2020.

RESUMEN: El queratoquiste odontogénico es una lesión con aspectos clínicos e histopatológicos específicos. La Organización Mundial de la Salud (OMS) en 2017 lo reclasificó de un tumor a un quiste. Se caracteriza como un quiste de desarrollo epitelial de las mandíbulas, que surge de los restos de la lámina dental. Representa del $3 \%$ al $11 \%$ de todos los quistes odontogénicos y del 7 al $11 \%$ de los quistes de los huesos gnáticos. Se destaca por su naturaleza agresiva y su alto potencial de recaídas. La mayoría de los casos se diagnostican en individuos de entre 10 y 40 años, con una leve preferencia por el sexo masculino, que ocurre más en la mandíbula. Radiográficamente, es radiotransparente y bien delimitado, predominantemente unilocular, y puede causar el desplazamiento de los dientes adyacentes. El presente estudio tiene como objetivo reportar el caso clínico de una paciente de 25 años, que presenta una lesión intraósea en el maxilar (posterior, lado izquierdo), asintomática, con un ligero aumento en el volumen bucal intraoral, que contiene el diente 28 , con una hipótesis diagnóstica de queratoquiste odontogénico. El paciente fue sometido al tratamiento quirúrgico de descompresión, con punción de líquido quístico, biopsia de la lesión y examen anatomopatológico posterior. La enucleación del tumor se realizó con osteotomía LeFort I de maxilar y reconstrucción con malla de titanio. Existe evidencia radiográfica de reparación ósea y reducción de la lesión. El paciente se encuentra en seguimiento periódico de 4 años y no presenta signos clínicos ni radiográficos de recaída. Debido a la agresividad del queratoquiste odontogénico, la tasa de recaída es alta. El conocimiento de las técnicas recomendadas para el tratamiento de los queratoquistes odontogénicos, y el seguimiento clínico y radiográfico del paciente, demuestran una disminución gradual del lumen de la lesión y sugieren neoformación ósea local, favoreciendo el pronóstico del caso.

PALABRAS CLAVE: quistes odontogénicos, maxilar, osteotomía, terapêutica.

\section{REFERENCES}

Alstad, V. \& Abtahi, J. Surgical removal of keratocystic odontogenic tumours via a Le Fort I osteotomy approach: a retrospective study of the recurrence rate. Int. J. Oral Maxillofac. Surg., 46(4):434-9, 2017.

Bataineh, A. B. \& al Qudah, M. Treatment of mandibular odontogenic keratocysts. Oral Surg. Oral Med. Oral Pathol. Oral Radiol. Endod., 86(1):42-7, 1998.

Brøndum, N. \& Jensen, V. J. Recurrence of keratocysts and decompression treatment. A long-term follow-up of forty-four cases. Oral Surg. Oral Med. Oral Pathol., 72(3):265-9, 1991.

Buchanan, E. P. \& Hyman, C. H. Le Fort I osteotomy. Semin. Plast. Surg., 27(3):149-54, 2013.

Byun, J. H.; Kang, Y. H.; Choi, M. J. \& Park, B. W. Expansile keratocystic odontogenic tumor in the maxilla: immunohistochemical studies and review of literature. J. Korean Assoc. Oral Maxillofac. Surg., 39(4):182-7, 2013.

Cakur, B.; Miloglu, O.; Yolcu, U.; Göregen, M. \& Gürsan, N. Keratocystic odontogenic tumor invading the right maxillary sinus: a case report. J. Oral Sci., 50(3):345-9, 2008.

Catunda, I. S; Melo, A. R.; Medeiros Júnior, R.; Queiroz, I. V.; da Fonte Neto, A. S. \& Leão, J. C. Osteotomia Le Fort I: aspectos de interesse no tratamento de nasoangiofibroma juvenil. Rev. Cir. Traumatol. Buco-Maxilo-Fac., 11(4):9-12, 2011.

Colreavy, M. P.; Baker, T.; Campbell, M.; Murphy, M. \& Lyons, B. The safety and effectiveness of the Le Fort I approach to removing central skull base lesions. Ear Nose Throat J., 80(5):315-8, 320, 2001.

Habibi, A.; Saghravanian N.; Habibi, M.; Mellati, E. \& Habibi, M. Keratocystic odontogenic tumor: a 10-year retrospective study of 83 cases in an Iranian population. J. Oral Sci., 49(3):229-35, 2007.

Hunter, R. B.; Zaretsky, L. S.; Nuovo, M. \& April, M. M. Bilateral odontogenic keratocysts of the maxillary sinus. Am. J. Orolaryngol., 17(4):269-71, 1996.

Johnson, N. R.; Batstone, M. D. \& Savage, N. W. Management and recurrence of keratocystic odontogenic tumor: a systematic review. Oral Surg. Oral Med. Oral Pathol. Oral Radiol., 116(4):e271-6, 2013.

Kaczmarzyk, T.; Mojsa, I. \& Stypulkowska, J. A systematic review of the recurrence rate for keratocystic odontogenic tumour in relation to treatment modalities. Int. J. Oral Maxillofac. Surg., 41(6):75667, 2012.

Karci, B.; Oner, K.; Günhan, O.; Ovül, I. \& Bilgen, C. Nasomaxillary osteotomy in lesions of the central compartment of the middle cranial base. Rhinology, 39(3):160-5, 2001.

Khalique, N. \& Rippin, J. W. Odontogenic keratocyst in an infant. Br. Dent. J., 172(7):282-3, 1992.

Kolokhytas, A.; Fernandes, R. P.; Pazoki, A. \& Ord, R. A. Odontogenic keratocyst: to decompress or not to decompress? A comparative study of decompression and enucleation versus resection/ peripheral ostectomy. J. Oral Maxillofac. Surg., 65(4):640-4, 2007.

Korpi, J. T.; Kainulainen, V. T.; Sándor, G. K. B. \& Oikarinen, K. S. Removal of large complex odontoma using Le Fort I osteotomy. J. Oral Maxillofac. Surg., 67(9):2018-21, 2009.

Kunihiro, T.; Kawana, H.; Kodaka, R. \& Oba, T. Keratocystic odontogenic tumor invading the maxillary sinus: a case report of collaborative surgery between an oral surgeon and an otorhinolaryngologist. J. UOEH, 36(4):251-6, 2014.

Lacarbonara, M.; Marzo, G.; Lacarbonara, V.; Monaco, A. \& Capogreco, M. Presentation of a keratocystic odontogenic tumor with agenesis: a case report. J. Med. Case Rep., 8:126, 2014. 
Lee, S. T.; Kim, S. G.; Moon, S. Y.; Oh, J. S.; You, J. S. \& Kim, J. S. The effect of decompression as treatment of the cysts in the jaws: retrospective analysis. J. Korean Assoc. Oral Maxillofac. Surg., 43(2):83-7, 2017.

Leite Segundo, A. V.; Bozzetto-Ambrosi, P.; Cauas, M.; Caubi, A. F. \& Azevedo Filho, H. R. C. Utilização da osteotomia Le Fort I na abordagem cirúrgica de carcinoma epidermóide de base de crânio. Rev. Cir. Traumatol. Buco-Maxilo-Fac., 7(2):55-60, 2007.

Lewark, T. M.; Allen, G. C.; Chowdhury, K. \& Chan, K. H. Le Fort I osteotomy and skull base tumors: a pediatric experience. Arch. Otolaryngol. Head Neck Surg., 126(8):1004-8, 2000.

Lowlicht, R. A.; Jassin, B.; Kim, M. \& Sasaki, C. T. Clarence T. Sasaki. Long-term effects of Le Fort I osteotomy for resection of juvenile nasopharyngeal angiofibroma on maxillary growth and dental sensation. Arch. Otolaryngol. Head Neck Surg., 128(8):923-7, 2002.

MacDonald-Jankowski, D. S. Keratocystic odontogenic tumour: systematic review. Dentomaxillofac. Radiol., 40(1):1-23, 2011.

Madras, J. \& Lapointe, H. Keratocystic odontogenic tumour: reclassification of the odontogenic keratocyst from cyst to tumour. J. Can. Dent. Assoc., 74(2):165-165h, 2008.

Marker, P.; Brøndum, N.; Clausen, P. P. \& Bastian, H. L. Treatment of large odontogenic keratocysts by decompression and later cystectomy: a long-term follow-up and a histologic study of 23 cases. Oral Surg. Oral Med. Oral Pathol. Oral Radiol. Endod., 82(2):122-31, 1996

Meiselman, F. Surgical management of the odontogenic keratocyst: conservative approach. J. Oral Maxillofac. Surg, 52(9):960-3, 1994.

Moura, B. S.; Cavalcante, M. A. \& Hespanhol, W. Tumor odontogênico ceratocístico. Rev. Col. Bras. Cir., 43(6):466-71, 2016.

Paris, J.; Guelfucci, B.; Moulin, G.; Zanaret, M. \& Triglia, J. M. Diagnosis and treatment of juvenile nasopharyngeal angiofibroma. Eur. Arch. Otorhinolaryngol., 258(3):120-4, 2001.

Regezi, J. A.; Sciubba, J. J. \& Jordan, R. Patologia Oral: Correlações Clinicopatológicas. $5^{\text {th }}$ ed. Philadelphia, Elsevier, 2008.

Schultz, C. B.; Pajarola, G. F. \& Grätz, K. W. Therapy and course of recurrent odontogenic keratocyst. S case report. Schweiz. Monatsschr. Zahnmed., 115(6):554-65, 2005.

Scolozzi, P.; Martinez, A.; Lombardi, T. \& Jaques, B. Lateral antrotomy as a surgical approach for maxillary sinus: a modified technique with free bone flap repositioning and fixation with a titanium plate. J. Oral Maxillofac. Surg., 67(3):689-92, 2009.

Shear, M: The aggressive nature of the odontogenic keratocyst: is it a benign cystic neoplasm? Part 1. Clinical and early experimental evidence of aggressive behavior. Oral Oncol., 38(3):21926, 2002.

Shenoy, P.; Paulose, K. O.; Al Khalifa, S. \& Sharma, R. L. Odontogenic keratocyst involving the maxillary antrum. J. Laryngol. Otol., 102(12):1168-71, 1988.

Tucker, W. M.; Pleasants, J. E. \& MacComb, W. S. Decompression and secondary enucleation of a mandibular cyst: report of case. J. Oral Surg., 30(9):669-73, 1972.

Waldron, C. A. Cistos e Tumores Odontogênicos. In: Neville, B. W.; Damm, D. D.; Allen, C. M. \& Bouquot, J. E. Patologia Oral \& Maxilofacial. Rio de Janeiro, Elsevier, 2009. pp.679-742.

Wetmore, S. J.; Billie, J. D.; Howe, A. \& Wetzel, W. Odontogenic keratocyst: diagnosis and treatment. Otolaryngol. Head Neck Surg., 91(2):167-72, 1983.

Wood, G. D. \& Stell, P. M. Osteotomy at the Lefort I level. A versatile procedure. Br. J. Oral Maxillofac. Surg., 27(1):33-8, 1989.

Woodall, B. N. \& Wood, B. P. Radiological case of the month. Odontogenic keratocyst of the maxillary sinus. Am. J. Dis. Child., 147(2):203-4, 1993.
Zachariades, N., Papanicolaou, S. \& Triantafyllou, D. Odontogenic keratocysts: Review of the literature and report of sixteen cases. J. Oral Maxillofac. Surg., 43(3):177-82, 1985.

Zhao, Y. F.; Wei, J. X. \& Wang, S. P. Treatment of odontogenic keratocysts: a follow-up of 255 Chinese patients. Oral Surg. Oral Med. Oral Pathol. Oral Radiol. Endod., 94(2):151-6, 2002.

Zhou, J.; Wang, L.; Chen, Z.; Qiu, J. \& Dong, Q. Giant keratocystic odontogenic tumor of the maxillary sinus and zygoma: a case report. Oncol. Lett., 8(6):2675-7, 2014.

Corresponding author:

Giulia Quarentei Barros Brancher

Residency training

program in Oral and Maxillofacial Surgery

at Hospital dos Fornecedores de Cana de Piracicaba

Piracicaba, São Paulo

BRAZIL

Email:dr.lucasmaxilofacial@hotmail.com

Received: 05-06-2019

Accepted: 15-10-2019 